\begin{tabular}{l|l|l} 
Jurnal Eksplorasi Akuntansi & $\begin{array}{l}\text { e-ISSN : 2656-3649 (Online) } \\
\text { http://jea.ppj.unp.ac.id/index.php/jea/index }\end{array}$
\end{tabular}

\title{
Pengaruh Corporate Social Responsibility dan Mekanisme GCG terhadap Manajemen Laba Perusahan Manufaktur yang Terdaftar di Bursa Efek Indonesia
}

\author{
Rizki Zulkarnain ${ }^{1 *}$, Nayang Helmayunita ${ }^{2}$ \\ ${ }^{1,2}$ Fakultas Ekonomi, Universitas Negeri Padang \\ *Korespondensi: rizkizulkarnain289@gmail.com
}

\begin{abstract}
The purpose of this study was to analyze the effect of CSR disclosure, independent commissioner, audit committee and managerial ownership on earnings management. The data used in this study are annual and financial reports in manufacturing companies listed on the indonesia stock exchange (idx) in the period 2015-2019. The method of taking data samples using purposive sampling method based on certain criteria. Based on the retrieval method obtained A sample of 195 companies. Hypothesis testing in this study uses multiple linear regression analysis. The results show that the independen commissioner, the audit committee has no effect on earnings management and the CSR disclosure of managerial ownership has an effect on earnings management.
\end{abstract}

Keywords: corporate social responsibility; good corporate governance; earning management

How to cite (APA $6^{\text {th }}$ style)

Zulkarnain, R \& Helmayunita, N. (2021). Pengaruh Corporate Social Responsibility, dan Mekanisme GCG terhadap Manajemen Laba Perusahan Manufaktur yang Terdaftar di Bursa Efek Indonesia. Jurnal Eksplorasi Akuntansi. 3(3). 547-566.

\section{PENDAHULUAN}

Pengungkapan informasi pada perusahaan tercermin dalam laporan keuangan perusahaan. Laporan keuangan tidak hanya berfungsi sebagai pertanggungjawaban manajemen kepada pemilik modal tetapi juga dapat berfungsi sebagai media komunikasi yang efektif kepada semua pihak tentang kinerja dan prospek perusahaan dimasa yang akan datang. Menurut PSAK No. 1, laporan keuangan adalah sebuah dokumen yang penting, karena menyajikan sumber informasi yang berguna bagi pengguna laporan keuangan dalam mengambil keputusan ekonomik. Sebuah perusahaan memiliki laporan keuangan terdiri dari neraca, laporan laba rugi, laporan perubahan ekuitas, laporan arus kas, dan catatan atas laporan keuangan. Dari berbagai macam komponen laporan keuangan diatas, laporan yang sangat penting adalah laporan laba rugi, karena di dalam laporan tersebut berisi informasi tentang laba yang berguna bagi pengguna informasi laporan keuangan tersebut. Tujuan dari informasi tersebut adalah untuk mengetahui kemampuan dan kinerja keuangan suatu perusahaan pada periode waktu tertentu..

Biasanya manajemen akan menggunakan berbagai metode akuntansi dan memilih metode akuntansi yang lebih menguntungkan perusahaan, namun tidak menyalahi aturan yang 
ada saat ini dalam mencapai target laba, ini menunjukkan bahwa perusahaan memiliki kebebasan dalam menggunakan metode akuntansi sesuai dengan prinsip akuntansi berterima umum (Generally Accepted Accounting Principles - GAAP) (Ghozali, 2014). Dengan metode akuntansi yang fleksibelitas maka memungkinkan manajer untuk melakukan tindakan manajemen laba. Praktik manajemen laba (earning management) secara umum dapat diartikan sebagai usaha manajer perusahaan dalam melakukan intervensi atau mempengaruhi informasi-informasi dalam laporan keuangan dengan tujuan untuk mengelabuhi stakeholder yang ingin mengetahui kinerja dan kondisi perusahaan (Sulistyanto, 2008). Sedangkan manajemen laba menurut (Scott, 2006) adalah "the choice by a manager of accounting policies so as to achieve some specific objective, manajemen laba dapat diartikan yaitu dalam memilih kebijakan akuntansi tertentu, keputusan manajer dianggap dapat mencapai tujuan yang diinginkan, baik itu untuk meningkatkan laba atau mengurangi kerugian yang dilaporkan. Salah satu faktor yang dapat mengurangi kredibilitas laporan keuangan dan menambah bias laporan keuangan adalah manajemen laba (Abdillah, 2014). Tindakan dari manajemen laba dapat mengakibatkan informasi laporan keuangan menjadi tidak akurat.

Manajemen laba timbul akibat adanya kondisi asimetri informasi. Asimetri informasi adalah adanya perbedaan informasi antara manajemen dan stakeholder yang menimbulkan masalah keagenan, sehingga informasi laporan keuangan yang sebenarnya tidak diketahui oleh stakehlders, karena bisa dimanipulasi oleh manajemen (Anggana \& Prastiwi, 2013). Penelitian (Dai, Y., Kong \& Wang, 2013) menunjukkan adanya hubungan yang positif antara asimetri informasi dengan manajemen laba. Artinya semakin tinggi asimetri informasi antara manajemen dengan pemegang saham maka akan semakin tinggi tingkat manajemen laba yang dilakukan manajemen. Selain dari asimetri informasi, ada beberapa motivasi yang mendorong manajemen untuk melakukan manajemen laba. Menurut (Scott, 2006), motivasi manajemen laba meliputi rencana bonus, biaya politik, perpajakan, penggantian CEO, dan lain-lain.

Manajemen laba biasanya dipengaruhi oleh berbagai faktor, salah satunya adalah pengungkapan CSR. Menurut (Kim et al., 2012), Corporate Social Responsibility (CSR) atau tanggung jawab sosial dan lingkungan adalah kegiatan tanggung jawab sosial yang diungkapkan oleh perusahaan agar investor, pelanggan, dan pihak stakeholder lainnya dapat menuntut transparansi yang lebih besar mengenai semua aspek bisnis. Adanya aktivitas pengungkapan CSR membuat manajemen dalam perusahaan lebih bebas untuk melakukan tindakan manajemen laba, karena aktivitas CSR ini dapat membuat respon positif dimata investor maupun masyarakat sehingga dapat menutupi kecurangan - kecurangan yang dilakukan oleh manajer. Hal ini didukung oleh penelitian (Suryani \& Herianti, 2015) dan (Wardani, 2018) yang menunjukkan bahwa CSR digunakan oleh manajemen sebagai tameng untuk menutupi praktik manajemen laba. Hal ini berarti dengan tingkat pengungkapan sosial dan lingkungan yang tinggi maka akan meningkatkan aktifitas manajemen laba atau yang biasa disebut dengan penelitian berpengaruh positif. Namun, (Putri \& Rohman, 2016) dan (Ardiani \& Sudana, 2018) yang menunjukkan bahwa CSR berpengaruh negatif terhadap manajemen laba. Hal ini berarti dengan tingkat pengungkapan sosial dan lingkungan yang tinggi maka akan mengurangi aktifitas manajemen laba.

Untuk melindungi kepentingan stakeholder, maka di perlukan keberadaan peraturan dan mekanisme pengendalian yang mengatur hubungan antara pihak - pihak yang berkepentingan tersebut. Mekanisme yang dimaksud adalah good corporate governance. Good Corporate Governance adalah sebuah aturan yang mengatur hubungan antara pengurus (pengelola perusahaan), pemegang saham, pihak kreditur, pemerintah, karyawan serta para pemegang internal dan eksternal lainnya yang berkaitan dengan hak-hak dan kewajiban mereka (FCGI, 2001). Manajemen melakukan praktik good corporate governance guna meningkatkan pengendalian dan transparansi atas operasional perusahaan sehingga pihak 
pengguna informasi (investor) menjadi lebih yakin atas pengembalian dana investasi yang mereka serahkan (Anwar \& Mulyadi, 2015).

Menurut (FCGI, 2001), ada empat prinsip penting yang dimiliki good corporate governance yaitu keadilan, transparansi, pertanggungjawaban dan akuntabilitas. Diterapkannya prinsip GCG dalam organisasi perusahaan bertujuan untuk dapat memperkecil lingkup manajemen untuk melakukan tindakan manajemen laba. Komisaris independen mempunyai peranan sangat penting dalam usaha menciptakan fairness dan responsibility di pasar modal. Komisaris independen dapat menjadi penengah dalam perselisihan antara manajer internal dan mengawasi kebijakan dewan direksi jika dikaitkan dengan prinsip dan aturan GCG (Pratiwi \& Wahyu, 2013). Tugas komisaris independen yaitu untuk melakukan pengawasan terhadap aktivitas operasional perusahaan. Melalui peranannya itu, komisaris independen dapat memberikan kontribusi yang efektif terhadap hasil dan proses penyusunan laporan keuangan agar terhindar dari kecurangan pelaporan keuangan.

Bukti empiris mendukung bahwa komisaris independen sebagai proksi dari good corporate governance mampu membatasi praktik manajemen laba (Prabaningrat, 2015) dan (Abduh \& Rusliati, 2018). Praktik manajemen laba dapat diatasi oleh komisaris independen melalui proses pengendalian dan pengawasannya terhadap operasional perusahaan serta hasil dan proses penyusunan laporan keuangan. Namun, (Sutino \& Khoiruddin, 2016) dan (Arlita, R, Bone \& Kesuma, 2019) menemukan bukti bahwa komisaris independen belum dapat membatasi praktik manajemen laba karena pemenuhan mekanisme ini hanya sebuah formalitas untuk dapat memenuhi regulasi saja.

Prinsip akuntabilitas dan transparansi dapat kita lihat melalui peran komite audit dalam hal memelihara kredibilitas proses penyusunan laporan keuangan. Komite audit bertugas membantu dewan komisaris dalam menjalankan tanggung jawabnya terutama dengan masalah yang berhubungan dengan kebijakan akuntansi perusahaan, pengawasan internal dan sistem pelaporan keuangan. Beberapa peneliti menyimpulkan bahwa keberadaan komite audit dapat membatasi praktik manajemen laba (Abduh \& Rusliati, 2018) dan (Wijayanti, P. R., \& Subardjo, 2018) Hal ini membuktikan bahwa komite audit yang dipilih oleh perusahaan bukan hanya sekedar pemenuhan peraturan tapi memang sesuai dengan independensi dan kompetensi yang dimilikinya sehingga dalam melakukan penelaahan terhadap laporan keuangan komite audit bisa mendeteksi ada atau tidaknya manajemen laba. Namun, (Suri \& Dewi, 2018) menemukan bukti bahwa manajemen laba justru terjadi pada saat perusahaan memiliki komite audit yang sesungguhnya diharapkan dapat mengurangi tindakan manajemen laba. Hal ini menunjukkan bahwa komite audit yang dibentuk hanya bersifat mandatory terhadap peraturan yang berlaku. Selain itu, definisi financial literacy yang harus dimiliki oleh anggota komite audit kurang jelas yang menyebabkan tiap perusahaan sampel kemungkinan memiliki definisi yang berbeda dalam menentukan kriteria dari komite audit ini.

Kepemilikan saham perusahaan juga dapat meminimalisir praktik manajemen laba (Abdillah, 2014). Hal ini dikarenakan kepemilikan manajerial akan meningkatkan prinsip dari GCG yaitu prinsip transparansi yang diwujudkan dalam bentuk keterbukaan dalam melaksanakan proses pengambilan keputusan dan dalam mengumumkan informasi material yang relevan mengenai perusahaan. Kepemilikan manajerial yang besar dapat mensejajarkan antara kepentingan pemilik atau pemegang saham dengan kepentingan manajer (Jensen \& Meckling, 1976), sehingga secara langsung manajer ikut merasakan manfaat dari keputusan yang diambil dan ikut pula menanggung kerugian sebagai konsekuensi dari pengambilan keputusan yang salah. Namun, (Mangkusuroyo \& Jati, 2017) dan (Arlita, R, Bone \& Kesuma, 2019) menemukan hasil bahwa kepemilikan manajerial berpengaruh positif signifikan terhadap manajemen laba. Hal ini dikarenakan jumlah kepemilikan manajerial yang rendah sehingga tidak adanya rasa kepemilikan manajemen terhadap perusahaan yang dikelolanya. 
Hasil yang tidak konsisten ini menunjukkan bahwa penelitian mengenai pengaruh kepemilikan manajerial terhadap manajemen laba perlu diteliti kembali.

Berdasarkan uraian latar belakang dan penelitian terdahulu maka perlu dilakukan penelitian mengenai hubungan csr, mekanisme gcg, terhadap praktik manajemen laba. Mengacu pada hasil-hasil penelitian empiris yang dilakukan, terdapat ketidakkonsistenan hasil untuk variabel mekanisme good corporate governance untuk itu peneliti ingin meneliti kembali tentang mekanisme good corporate governance tersebut. Dan penelitian ini juga beda dari penelitian sebelumnya, karena penelitian sebelumnya menggunakan variabel mekanisme good corporate governance dan variabel ukuran perusahaan dan leverage. Namun pada penilitian ini peneliti menambahkan variabel pengungkapan corporate social responsibility. Objek penelitian yang dilakukan adalah perusahaan manufaktur, alasan peneliti memilih sampel untuk menggunakan perusahaan manufaktur karena taraf perusahaan yang besar dan sangat berpengaruh dalam perkembangan perekonomian Negara dan komponen laba dalam laporan keuangan perusahaan manufaktur juga semakin meningkat. Dengan demikian kemungkinan untuk melakukan aktivitas manajemen laba sangat besar.

\section{REVIUW LITERATUR DAN HIPOTESIS}

\section{Teori Keagenan}

Grand theory yang melandasi penelitian ini adalah teori keagenan atau agency theory. Jensen \& Meckling, 1976 menyatakan bahwa kaitan keagenan adalah kontrak antara manager (agent) dan investor (principal). Marpaung \& Latrini, 2014 menjelaskan bahwa teori keagenan adalah hubungan antara manajemen (agent) dengan pemegang saham (principal) dalam suatu perusahaan. Hubungan ini terkadang menciptakan dua kepentingan yang berbeda antara manajemen maupun pemegang saham. Pemegang saham sebagai pihak principal memaksimalkan kesejahteraan dirinya dengan profitabilitas yang selalu meningkat dengan cara mengadakan kontrak. Manajer sebagai agent terpacu untuk mengoptimalkan pemenuhan kebutuhan ekonomi dan psikologisnya.

Sebagai pengelola perusahaan, informasi internal dan prospek perusahaan di masa yang akan datang lebih banyak diketahui oleh manajer dibandingakan dengan pemilik modal. Kondisi ini dikenal dengan asimetri informasi. Manajer biasanya memiliki informasi yang lebih banyak dibandingkan dengan pemegang saham yang dapat mengakibatkan manajer melakukan tindakan-tindakan sesuai dengan keinginan dan kepentingan untuk memaksimalkan kepentingannya. Sedangkan, bagi pemilik modal hanya memiliki informasi sedikit yang akan mengakibatkan pemegang saham tidak mengetahui kondisi perusahaan yang sebenarnya. Sehingga, pemegang saham cukup sulit untuk mengontrol secara efektif tindakan yang dilakukan oleh manajemen

\section{Asimetri Informasi}

Asimetri informasi adalah keadaan manajer yang memiliki informasi yang lebih dari pihak eksternal perusahaan. Menurut (Rahmawati \& Triatmoko, 2007) ada 2 tipe asimetri informasi yaitu: (1) adverse selection, yaitu asimetri informasi yang mana satu pihak atau lebih melangsungkan atau yang akan melansungkan transaksi usaha, atau tranasaksi usaha potensial yang memiliki informasi lebih atas pihak lain. Asimetri ini dapat terjadi ketika manajer perusahaan atau pihal dalam (insiders) lainnya lebih mengetahui kondisi kini dan prospek luar perusahaan daripada investor luar. (2) moral hazard, yaitu asimetri informasi yang mana suatu pihak yang melangsungkan suatu transaksi usaha atau transaksi usaha potensial dapat mengamati tindakan-tindakan mereka dalam menyelesaikan transaksitransaksi mereka sedangkan pihak-pihak lain tidak. Moral Hazard terjadi ketika adanya pemisahan pemilikan dengan pengendalian yang merupakan karakteristik kebanyakan perusahaan besar. 


\section{Pengungkapan Perusahaan}

Pengertian pengungkapan dalam laporan keuangan menurut Evans (2003) adalah "Disclosure means supplying information ini the financial statements including in the statements themselves, the notes to the statements and the supplementary disclosures associated with the statements". Ada dua jenis pengungkapan dalam hubungannya dengan persyaratan yang ditetapkan standar (Ghozali \& Chairi, 2014) yaitu : (1) Pengungkapan wajib. Pengungkapan wajib adalah pengungkapan minimum yang disyaratkan oleh standar akuntansi yang berlaku. Pengungkapan yang paling lazim digunakan dalam praktik yaitu pengungkapan yang cukup (Adequate Disclosure).

Pengungkapan minimal yang disajikan sesuai dengan peraturan yang berlaku disebut dengan pengungkapan yang cukup. (2) Pengungkapan sukarela. Pengungkapan sukarela adalah pengungkapan yang disajikan tanpa harus sesuai standar atau ketentuan yang berlaku atau pengungkapan yang dilakukan secara sukarela oleh perusahaan. Pengungkapan sukarela yang dilakukan oleh perusahaan membuat manajemen bebas untuk memberi informasi akuntansi maupun informasi lainnya di luar standar pengungkapan yang sudah ditetapkan.

\section{Good Corporate Governance}

Good corporate governance adalah sebuah peraturan yang mengatur hubungan antara pemegang saham, pengurus (pengelola perusahaan), pihak kreditur, pemerintah, karyawan, serta para pemegang kepentigan internal dan eksternal lainnya yang berkaitan dengan hakhak dan kewajiban mereka (YYPMI, 2002). Good corporate governance pada dasarnya merupakan sebuah konsep yang memiliki kaitan tentang struktur perseroan, pembagian tugas, pembagian wewenang dan pembagian tanggung jawab masing-masing unsur dari perseroan.

Pada tahun 2015, G20 Finance Ministers ND Central Bank Governors Meeting bersama dengan Organisation for Economic Coperation and Development (G20/OECD) memperbaiki prinsip yang harus diterapkan untuk menerapkan GCG. Prinsip-prinsip GCG diterapkan dalam perusahaan secara konsisten agar dapat menghambat aktivitas manajemen laba yang dilakukan manajemen. Prinsip-prinsip GCG dalam perusahaan diimplementasikan agar dapat membantu mengatasi masalah tersebut.

\section{Manajemen Laba}

Scott, 2006 membagi cara pemahaman atas manajemen laba menjadi dua. Pertama, melihatnya sebagai prilaku oportunistik manajer untuk memenuhi kepentingannya dalam menghadapi kontrak kompensasi, kontrak utang, dan poitical costs (Opportunistic Earnings Management). Manajemen laba yang dipilih oleh manajemen sangat tergantung pada motif atau tujuan manajemen laba itu sendiri. Pola manajemen laba dapat dikelompokkan menjadi 4 menurut (Scott, 2006) yaitu: Taking a bath, Income maximization, Income minimization and Income smoothing.

Jenis atau pola manajemen laba yang sering dilakukan manajemen adalah income smoothing. Income smoothing akan menghasilkan suatu laporan laba yang terlihat stabil dan tidak beresiko tinngi. Hal ini tentu akan lebih menarik perhatian para investor untuk menanamkan modalnya.

\section{Discretionary Accruals}

Penggunaan dasar akrual merupakan salah satu asumsi yang digunakan dalam penyusunan lapoaran keuangan yang telah ditetapkan dalam standar akuntansi keuangan. Semua kejadian yang bersifat operasional pada suatu tahun yang berpengaruh terhadap arus kas disebut dengan akrual. Total akrual ini kemudian dibagi menjadi discretionary accruals dan non discretionary accruals. 
Discretionary accruals merupakan hasil dari pilihan kebijakan akuntansi yang dilakukan oleh manajemen, sedangkan nondiscretionary accrual merupakan akrual yang terjadi disebabkan oleh sifat usaha perusahaan. Subramanyam, 2010 menyatakan bahwa discretionary accruals memungkinkan manajer mencerminkan informasi privat mereka. Hal ini akan meningkatkan kemampuan laba untuk mencerminkan nilai ekonomis perusahaan. Namun pada saat yang sama, discretionary accruals sendiri memungkinkan manajer untuk terlibat dalam pelporan yang opportunistik untuk memaksimalkan kemakmuran mereka.

\section{Pengembangan Hipotesis \\ Pengungkapan CSR terhadap Manajamen Laba}

Manajemen laba adalah sebuah tindakan untuk meningkatkan atau menurunkan laba bersih yang dilakukan manajer untuk dilaporkan pada laporan keuangan. Seperti yang sudah dijelaskan oleh teori keagenan, bahwa praktik manajemen laba ini dipengaruhi oleh konflik kepentingan antara manajemen sebagai agen dan pemilik perusahaan sebagai principals yang timbul karena pihak principals sebagai pemilik perusahaan menginginkan perusahaan menghasilkan laba yang tinggi yang dapat memberikan manfaat kesejahteraan bagi principals, disisi lain agent diberi wewenang dan tanggungjawab untuk mengelola perusahaan dan berupaya untuk meningkatkan utilitasnya sendiri dan menyalahgunakan kepercayaan principals sebagai pemilik perusahaan (Ellen dan Juniarti, 2013).

Salah satu pengungkapan informasi yang dilakukan pihak perusahaan kepada pihak ketiga melalui laporan tahunan disebut pengungkapan CSR. Menurut (Kim et al., 2012) adanya kegiatan tanggung jawab sosial pada laporan tahunan akan membuat informasi keuangan lebih bagi pihak yang menggunakan laporan keuangan. Perusahaan yang lebih banyak mengungkapkan informasi mengenai aktivitas perusahaannya akan lebih membatasi praktik manajemen laba. Hal ini didukung oleh penelitian (Putri \& Rohman, 2016) yang telah membuktikan bahwa perusahaan akan mengurangi praktik manajemen laba jika melakukan pengungkapan corporate social responsibility. Oleh karena itu, semakin baik tingkat pengungkapan CSR maka praktik manajemen laba semakin menurun. Berdasarkan penjelasan diatas, dapat dirumuskan hipotesis sebagai berikut:

$\mathbf{H}_{1}$ : CSR berpengaruh signifikan negatif terhadap manajemen laba.

\section{Komisaris Independen terhadap Manajemen Laba}

Di dalam teori agensi di jelaskan secara mendasar tentang hubungan kontrak dan pendelegasian tugas oleh pemilik perusahaan (principal) kepada manajer (agent). Pihak principal sebagai pemilik menginginkan profitabilitas yang selalu meningkat akan modal yang mereka investasikan, sedangkan manajemen sebagai agent menginginkan maksimalisasi kebutuhan ekonomi secara pribadi ats kinerja yang mereka lakukan (Jensen \& Meckling, 1976). Adanya perbedaan informasi (information asymmetry) juga menyebabkan adanya masalah keagenan, karena perbedaan pengetahuan informasi dari pihak manajemen (agent) dan stakeholder (principal) sehingga manajemen bisa memanipulasi informasi laporan keuangan tanpa diketahui stakeholder kebenaran sebenarnya (Anggana \& Prastiwi, 2013). Hal ini adalah suatu moral hazard yang merupakan bentuk dari manajemen laba. Untuk meminimalisir masalah keagenan tersebut, maka di perlukan mekanisme pengawasan terhadap kinerja manajer agar bertindak sesuai dengan keinginan prinsipal. Terkait mekanisme tersebut maka keberadaan komisaris independen memiliki fungsi pengawasan terhadap manajer. (Pratiwi \& Wahyu, 2013) menyatakan komisaris independen dapat menjadi penengah dalam perselisihan antara manajer internal dan mengawasi kebijakan dewan direksi.

Bukti empiris mendukung bahwa komisaris independen sebagai proksi dari corporate governance mampu membatasi praktik manajemen laba (Prabaningrat, 2015). Komisaris indpenden dapat membatasi praktek manajemen laba melalui proses pengendalian dan 
pengawasannya terhadap operasional perusahaan serta hasil dan proses penyusunan laporan keuangan. Hasil penelitiannya memberikan kesimpulan bahwa semakin besar komposisi dewan komisaris yang berasal dari luar perusahaan akan semakin kecilnya tindakan manajemen laba. Berdasarkan uraian diatas, hipotesis berikut diajuakan:

$\mathbf{H}_{2}$ : Komisaris independen berpengaruh signifikan negatif terhadap manajemen laba.

\section{Komite Audit terhadap Manajemen Laba}

Asimetri informasi yang disebabkan adanya perbedaan informasi antara agent dan principal tentang kondisi suatu perusahaan, telah memberikan peluang agent untuk melakukan moral hazard dengan cara manipulasi kinerja mereka dalam komponen laporan keuangan untuk tujuan pribadi. Hal ini merupakan suatu bentuk dari manajemen laba. Untuk meminimalisir bentuk kecurangan yang dilakukan manajer terhadap lapora keuangan yang mereka buat, maka diperlukan pengawasan oleh pihak ketiga yang independen terhadap proses laporan keuangan, yakni komite audit independen (Wardhani \& Joseph, 2010).Komite audit adalah komite yang dibentuk oleh dewan komisaris melalui surat keputusan (SK) dewan komisaris, keberadaan komite audit sangat penting bagi pengelolaan perusahaan disebabkan bertugas membantu dewan komisaris dalam melakukan fungsi pengawasan atas kinerja pengendalian internal perusahaan, memastikan kualitas laporan keuangan, dan meningkatkan efektivitas fungsi audit (Firdausya et al., 2013). Dalam kaitannya dengan manajemen laba, perusahaan yang memiliki komite audit mampu meminimalisir tindak kecurangan yang dilakukan manajer melalui fungsi pengawasan terhadap sistem pelaporan keuangan.

Dalam penelitiannya pada pasar modal Indonesia menyimpulkan bahwa komite audit mampu mengurangi aktivitas manajemen laba. (Abduh \& Rusliati, 2018). Keberadaan anggota komite audit independen mampu mengoptimalkan fungsi pengawasan yang menjadi tanggung jawab penuh dari dewan komisaris. Komite audit mampu meredam potensi terjadinya kecurangan baik terhadap operasi perusahaan maupun laporan keuangan. Dari penjelasan tersebut terlihat bahwa keberadaan komite audit yang dapat mengurangi aktivitas manajemen laba. Berdasarkan uraian tersebut, maka dapat diajukan hipotesis yaitu:

$\mathbf{H}_{3}$ : Komite audit berpengaruh signifikan negatif terhadap manajemen laba

\section{Kepemilikan Manajerial terhadap Manajemen Laba}

Jumlah kepemilikan saham manajerial dalam perusahaan akan meningkatkan tanggung jawab manajer terhadap kinerja mereka, karena dengan keputusan dan kinerja manajer tersebut dapat mempengaruhi tingkat laba dan risiko yang mereka secara pribadi. Sehingga hal tersebut mampu mengurangi masalah keagenan yang terjadi dalam perusahaan dengan adanya kepemilikan manajerial. Menurut (Ujiyantho \& Pramuka, 2007) manajemen laba sangat ditentukan oleh motivasi manajer perusahaan. Motivasi yang berbeda akan menghasilkan besaran manajemen laba yang berbeda, seperti antara manajer yang juga sekligus sebagai pemegang saham dan manajer yang tidak sebagai pemegang saham.

Hasil penelitan (Wijayanti, P. R., \& Subardjo, 2018) dalam penelitiannya pada pasar modal Indonesia telah membuktikan bahwa kepemilikan manajerial mampu menjadi mekanisme good corporate governance yang dapat mengurangi masalah ketidakselarasan kepentingan anatara manajer dengan dengan pemilik perusahaan. Semakin besar kepemilikan manajer pada perusahaan, maka semakin rendah kecenderungan manajer melakukan aktivitas manajemen laba. Hal itu dikarenakan adanya keselarasan tujuan manajer dengan tujuan pemegang saham. Tetapi jika semakin kecil kepemilikan manajerial maka semakin tinggi kecenderungan manajemen untuk melakukan manajemen laba. Berdasarkan uraian terebut dapat diajukan hipotesis: 
$\mathbf{H}_{4}$ : Kepemilikan manajerial berpengaruh signifikan negatif terhadap manajemen laba

\section{METODE PENELITIAN}

\section{Sampel dan Jenis Penelitian}

Jenis penelitian yang dilakukan pada penelitian ini adalah kausal komparatif. Populasi dalam penelitian ini adalah perusahaan Manufaktur yang terdaftar di Bursa Efek Indonesia (BEI) pada periode pengamatan pada tahun 2015 sampai tahun 2019. Jumlah sampel dalam penelitian ini adalah 41 perusahaan Manufaktur yang terdaftar di Bursa Efek Indonesia (BEI) pada periode pengamatan pada tahun 2015 sampai tahun 2019. Metode pengambilan sampel pada penelitian ini menggunakan metode purposive sampling yaitu pengambilan sampel sesuai dengan kriteria tertentu. Kriteria tersebut meliputi:

\section{Tabel 1}

Kriteria Pemilihan Sampel

\begin{tabular}{clc}
\hline No. & \multicolumn{1}{c}{ Keterangan } & Jumlah Perusahaan \\
\hline 1. & $\begin{array}{l}\text { Perusahaan manufaktur yang terdaftar di BEI pada tahun 2015- } \\
\text { 2019 }\end{array}$ & 162 \\
2. & $\begin{array}{l}\text { Perusahaan manufaktur yang tidak memiliki data lengkap terkait } \\
\text { dengan variabel penelitian }\end{array}$ & $(25)$ \\
3. & $\begin{array}{l}\text { Perusahaan manufaktur yang menyajikan laporan keuangan } \\
\text { menggunakan mata uang dollar }\end{array}$ & $(19)$ \\
4. & $\begin{array}{l}\text { Perusahaan yang tidak menerbitkan annual report dan laporan } \\
\text { keuangan secara lengkap dan konsisten selama tahun 2015-2019 }\end{array}$ \\
5. & Perusahaan manufaktur yang memiliki laba negative & $(41)$ \\
6. & Data Outlire & $(28)$ \\
& Jumlah sampel per tahun & $(10)$ \\
& Jumlah sampel 2015-2019 & 41 \\
\hline
\end{tabular}

\section{Jenis, Sumber dan Teknik Pengumpulan Data}

Jenis data yang digunakan dalam penelitian ini ialah data sekunder atau data tidak langsung. Data sekunder berupa penelitian yang dipublikasikan, analisis dokumen, dan informasi dari database perusahaan. Sumber data yang diambil berupa laporan keuangan dan laporan tahunan (annual report) perusahaan manufaktur yang terdaftar di Bursa Efek Indonesia. Sumber data data dapat diperoleh secara langsung melalui akses ke http://www.idx.co.id/ dan periode dalam penelitian ini 2015-2019

\section{Variabel Penelitian dan Pengukuran}

Variabel dependen pada penelitian ini adalah Manajemen laba ialah sebuah kebijakan manajer dalam memilih kebijakan akuntansi dari standar yang ada dan secara ilmiah dapat memaksimumkan utilitas mereka dan nilai pasar perusahaan (Scott, 2006). Manajemen laba dapat diukur dengan proxy discretionary accrual (DA). Penelitian mengukur discretionary accrual dengan menggunakan model Jones yang dimodifikasi. Model ini dianggap paling baik diantara model lain yang sama-sama digunakan untuk mengukur manajemen laba. 


\section{a. Model Jones yang dimodifikasi}

Perhitungan besarnya discretionary accrual dilakukan dengan tiga langkah :

1). Menghitung Total accrual

Total Akrual yang diterapkan dalam penelitian ini menggunakan data arus kas dari aktivitas operasi yang langsung diambil dari laporan arus kas. Dengan pendekatan laporan arus kas maka total akrual dihitung sebagai berikut:

$$
\text { TACCit }=\text { EBXTit }- \text { OCFit }
$$

EBXTit = laba perusahaan i sebelum pos-pos luar biasa operasi yang dihentikan untuk periode $\mathrm{t}$

OCFit = operating cash flow perusahaan i untuk periode tetap

\section{2). Menghitung nondiscretionary accrual}

Dalam perusahaan manajemen laba yang dilakukan dapat dibedakan menjadi akrual non diskresi dan akrual diskresi. Model ini ditujukan untuk menghitung akrual yang diharapkan terjadi seiring dengan berubahnya aktivitas operasional perusahaan yaitu nondiscretionary accrual. Selisih antara total akrual dengan nondiscretionary accrual akan menggambarkan discretionary accrual atau akrual yang sengaja diterapkan manajemen untuk tujuan tertentu.

Penelitian mengukur discretionary accrual dengan menggunakan model Jones yang dimodifikasi. Model ini dianggap paling baik diantara model lain yang sama-sama digunakan untuk mengukur manajemen laba, yaitu :

TACCit $\quad=\mathrm{a}_{1}(1 /$ Tai,t -1$)+\mathrm{a}_{2}(\Delta$ REVit $-\Delta$ RECit $)+\mathrm{a}_{3}$ PPEit + cit.

TACCit $=$ total akrual untuk perusahaan $\mathrm{i}$ pada tahun $\mathrm{t}$, dibagi total asset untuk perusahaan i pada akhir tahun $\mathrm{t}-1$

TAi,t-1 = total asset untuk perusahaan i pada akhir tahun $\mathrm{t}-1$

$\triangle$ REVit $\quad=$ perubahan dalam pendapatan untuk perusahaan I pada akhir tahun $\mathrm{t}$, dibagi total asset perusahaan i pada akhir tahun t-1

$\Delta$ RECit $=$ perubahan dalam piutang bersih untuk perusahaan $\mathrm{i}$ pada tahun $\mathrm{t}$, dibagi total asset untuk perusahaan i pada akhir tahun $\mathrm{t}-1$

PPEit = aktiva tetap perusahaan $\mathrm{i}$ pada tahun $\mathrm{t}$ dibagi total asset perusahaan $\mathrm{i}$ pada akhir tahun t-1

Persamaan akrual total diatas determinasi dengan metode ordinary lest square. Estimasi $\mathrm{a}_{1}, \mathrm{a}_{2}$, $\mathrm{a}_{3}$ di dapat dari regresi OLS tersebut dan digunakan untuk mengitung nondiscretionary accruals sebagai berikut :

NDACCit $=\hat{a}_{1}(1 /$ TA,t-1 $)+\hat{a}_{2}(\Delta$ REVit $-\Delta$ RECit $)+\hat{a}_{3}$ PPEit $+\varepsilon$ it, dimana:

$\mathrm{NDACCi}=$ nondiscretionary accrual perusahaan i pada periode $\mathrm{t}$

$\hat{\mathrm{a}}_{1,} \hat{\mathrm{a}}_{2}, \hat{\mathrm{a}}_{3} \quad=$ fitted coefficient yang diperoeh dari persamaan (2)

\section{3). Menghitung discretionary accrual}

Discretionary accrual diestimasi dengan cara sebagai berikut : 


\section{DACCit $=$ TACCit - NDACCit}

Variabel independen yang pertam damentitian adalan CSR. Dalam penelitian ini peneliti mengukur CSR dengan menggunakan Corporate Social Responsibility Index (CSRI) yang mengacu pada pedoman instrumen Global Instrument Initiative (GRI) versi GRI4. Penghitungan CSR pada setiap perusahaan dilakukan dengan menggunakan pendekatan dikotomi, artinya dimana setiap kategori informasi pengungkapan CSR dalam instrumen penelitian diberi skor 1 jika kategori informasi yang diungkapkan ada dalam laporan tahunan, dan diberi nilai 0 jika kategori informasi tidak diungkapkan di dalam laporan tahunan (Arief, 2014). Variabel independen yang kedua dalam penelitian ini adalah komisaris independen dan diukur dengan menggunakan rasio jumlah komisaris independen terhadap jumlah seluruh anggota komisaris. Variabel independen yang ketiga dalam penelitian ini adalah komite audit.Komite audit di ukur dengan variabel dummy terbagi atas: 1) Komite audit telah terbentuk dan diketuai oleh komisaris independen, berjumlah minimal 3 orang dan salah satu anggota memiliki latar belakang pendidikan akuntansi atau keuangan diberi nilai 1. 2) Komite audit yang belum dapat memenuhi kriteria yang diberi nilai 0 . Variabel independen yang keempat dalam penelitian ini adalah kepemilikan manajerial diukur berdasarkan persentase saham yang dimiliki oleh pihak-pihak yang bekerja pada perusahaan.

\section{Metode Analisis Data}

\section{Analisis Deskriptif}

Analisis deskriptif merupakan analisis yang digunakan untuk memberikan gambaran distribusi, nilai rata-rata (mean), standard deviasi, maksimum, dan minimum pada masingmasing variabel penelitian.

\section{Uji Kelayakan Model (Pengujian Hipotesis) Analisis Regresi Linear Berganda}

Penelitian ini menggunakan metode analisis regresi linear berganda sebagai alat untuk menguji hipotesisnya. Analisis regresi linear berganda adalah analisis yang bertujuan untuk mengetahui hubungan fungsional antara variabel bebas (independent) secara bersama-sama terhadap variabel terikat (dependent). Persamaan regresinya adalah sebagai berikut:

$$
\mathrm{Y}=\beta 0+\beta 1 \mathrm{X} 1+\beta 2 \mathrm{X} 2+\beta 2 \mathrm{X} 3+\beta 2 \mathrm{X} 4+e
$$

\section{Keterangan:}

$\mathrm{Y}$ : Manajemen laba

$\mathrm{X} 1$ : CSR

$\mathrm{X} 2$ : Komisaris independen

X3 : Komite audit

$\mathrm{X} 4$ : Kepemilikan manajerial

$\beta 0$ : Konstanta

$\beta$ : Koefesien regresi

\section{Uji Koefisien Determinasi (Adjusted $\boldsymbol{R}^{2}$ )}

Uji Koefisien determinasi (Adjusted $R^{2}$ ) berfungsi untuk mengukur sejauhmana kemampuan model dalam menjelaskan variasi variabel terikat (dependen) (Imam Ghozali, 2018). Apabila angka koefisien determinasi semakin mendekati 1 (semakin besar), maka pengaruh variabel bebas (independent) terhadap variabel terikat (dependent) adalah semakin kuat, yang berarti variabel-variabel bebas (independent) memberikan hampir seluruh informasi yang dibutuhkan untuk memperkirakan variasi variabel terikat (dependent). 


\section{Uji F (Simultan)}

Uji F dilakukan untuk menguji apakah model yang digunakan signifikan atau tidak, sehingga dapat dipastikan apakah model tersebut dapat digunakan untuk memprediksi pengaruh variabel independen secara bersamaan terhadap variabel dependen (Imam Ghozali, 2018).

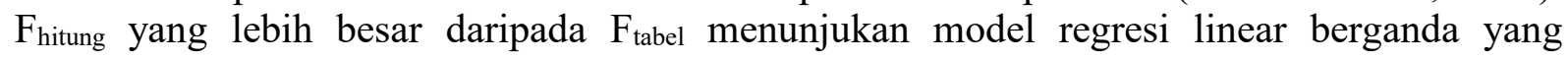
digunakan dapat dilanjutkan atau diterima, dengan tingkat kepercayaan untuk pengujian hipotesis adalah $95 \%$ atau $(\alpha)=0,05$.

\section{Uji Hipotesis (Uji t-Test)}

Uji statistik t dilakukan untuk menunjukan seberapa jauh pengaruh satu variabel dengan variabel lainnya (Imam Ghozali, 2018). Uji t juga dilakukan dengan melihat signifikansi t setiap variabel pada output hasil regresi dengan level signifikan $0,05(\alpha=5 \%)$. Apabila nilai signifikansi pada hasil output kecil dari 0,05 (hasil output $<0,05$ ) berarti terdapat hubungan atau pengaruh antara variabel independen dengan variabel dependen secara parsial dan begitu sebaliknya.

\section{HASIL DAN PEMBAHASAN}

Analisis Deskrptif

Analisis deskriptif merupakan analisis yang digunakan untuk memberikan gambaran distribusi, nilai rata-rata (mean), standard deviasi, maksimum, dan minimum pada masingmasing variabel penelitian. Teknik deskriptif yang dimaksud dalam penelitian ini adalah menafsirkan atau menginterpretasikan nilai rata-rata (mean), standard deviasi, maksimum, dan minimum pada masing-masing variabel penelitian.

Tabel 2

\section{Hasil statistik deskriptif}

\begin{tabular}{|c|c|c|c|c|c|}
\hline & $\mathrm{N}$ & Minimum & Maximum & Mean & Std. Deviation \\
\hline $\mathrm{Y}$ & 195 & $-0,07$ & 0,26 & 0,0780 & 0,06966 \\
\hline $\mathrm{X} 1$ & 195 & 0,03 & 0,43 & 0,1470 & 0,07341 \\
\hline X2 & 195 & 0,27 & 0,80 & 0,4175 & 0,10179 \\
\hline X3 & 195 & 0,00 & 1,00 & 0,8769 & 0,32937 \\
\hline $\mathrm{X} 4$ & 195 & 0,00 & 0,37 & 0,0331 & 0,08277 \\
\hline $\begin{array}{l}\text { Valid N } \\
\text { (listwise) }\end{array}$ & 195 & & & & \\
\hline
\end{tabular}

Hasil statistik deskriptif menampilkan nilai minimum, nilai maksimum, rata-rata dan standar deviasi dari masing variabel. Variabel CSR memiliki nilai minimum 0.03 dan nilai maksimum 0.43 dengan rata-rata sebesar 0.1470 dan standar deviasi 0.07341 . Variabel komisaris independen dengan nilai minimum 0.27 , nilai maksimum 0.80 dengan rata-rata sebesar 0.4175 dan standar deviasi 0.10179 . Variabel komite audit memiliki nilai minimum 0 dan nilai maksimum 1 dengan rata-rata sebesar 0.8769 dan standar deviasi 0.32937. Dan variabel kepemilikan manajerial dengan nilai minimum 0 nilai maksimum 0.37 dengan ratarata sebesar 0.0331 dan standar deviasi 0.08277 .

\section{Uji Asumsi Klasik}

Uji Normalitas

Pengambilan keputusan pengujian ini adalah jika nilai signifikan uji KolmogorofSmirnov $>0,05$ maka distribusi data dikatakan terdistribusi normal, sebaliknya nilai signifikan uji Kolmogorof-Smirnov $<0,05$ maka distribusi data dikatakan tidak terdistribusi normal. 
Tabel. 3

Hasil Uji Normalitas

Unstandardized Residual

\begin{tabular}{llr}
\hline N & & 195 \\
Normal Parameters & Mean & 0,0000000 \\
& Std. Deviation & 0,06763506 \\
Most Extreme Differences & Absolute & 0,045 \\
& Positive & 0,041 \\
& Negative & $-0,045$ \\
Test Statistic & & 0,045 \\
Asymp. Sig. (2-tailed) & &, $200^{\text {c,d }}$ \\
\hline
\end{tabular}

Hasil output di atas menunjukkan nilai Test Statistic 0,200 >0,05. Jadi dapat disimpulkan bahwa residual dinyatakan memenuhi asumsi normal.

\section{Uji Multikolinieritas}

Pengambilan keputusan pengujian ini adalah jika variabel mempunyai nilai Toleranse lebih dari 0,10 dan nilai VIF-nya (Variance Inflation Factor) lebih kecil dari 10 yang berarti tidak terjadi multikolinearitas pada model regresi (Imam Ghozali, 2018).

Tabel 4

Hasil Uji Multikolinieritas

\begin{tabular}{rrrrr}
\hline \multicolumn{2}{c}{} & \multicolumn{2}{c}{ Collinearity Statistics } \\
\multicolumn{2}{l}{ Model } & Tolerance & \multicolumn{2}{c}{ VIF } \\
\hline 1 & X1 & 0,965 & 1,037 \\
& X2 & 0,978 & 1,023 \\
& X3 & 0,966 & 1,035 \\
& X4 & 0,980 & 1,021 \\
\hline
\end{tabular}

Berdasarkan hasil pengujian multikolinieritas di atas, dapat dilihat bahwa nilai VIF (Variance Inflation Factor) untuk kedua variabel dibawah 10,00. Selain itu, nilai Tolerance kedua variabel independen menunjukkan angka lebih besar dari 0,10. Berdasarkan pengujian tersebut dapat disimpulkan bahwa model regresi telah memenuhi syarat multikolinieritas.

\section{Uji Autokorelasi}

Pengambilan keputusan pengujian ini adalah jika nilai Durbin-Watson yang di hasilkan berada dalam rentang 1,73 sampai dengan 2,20 maka dapat dinyatakan bahwa model yang digunakan terbebas dari gangguan autokorelasi. 


\begin{tabular}{|c|c|c|c|c|c|}
\hline Model & $\mathrm{R}$ & R Square & $\begin{array}{l}\text { Adjusted R } \\
\text { Square }\end{array}$ & $\begin{array}{l}\text { Std. Error of } \\
\text { the Estimate }\end{array}$ & $\begin{array}{l}\text { Durbin- } \\
\text { Watson }\end{array}$ \\
\hline 1 & $239^{\mathrm{a}}$ & 0,057 & 0,037 & 0,06834 & 2,013 \\
\hline
\end{tabular}

Dari tabel 5 dapat dilihat bahwa nilai Durbin-Watson (DW) adalah 2.013 yang berarti berada diantara dU sebesar 1.8076, dan 4-dU sebesar 2.1924 maka hasilnya $1.8076<2.013<$ 2.1924 sehingga dapat disimpulkan bahwa tidak terjadi autokorelasi atau tidak ada korelasi antara data berdasarkan urutan waktu dan model untuk penelitian ini dapat diterima.

\section{Uji Heteroskedastisitas}

Pengambilan keputusan pengujian ini adalah scatterplot. Apabila Scatterplot tidak membentuk pola tertentu (membentuk pola acak) maka tidak mengalami heteroskedastisitas. Sebaliknya jika scatterplot membentuk pola tertentu maka mengalami gangguan heteroskedastisitas.

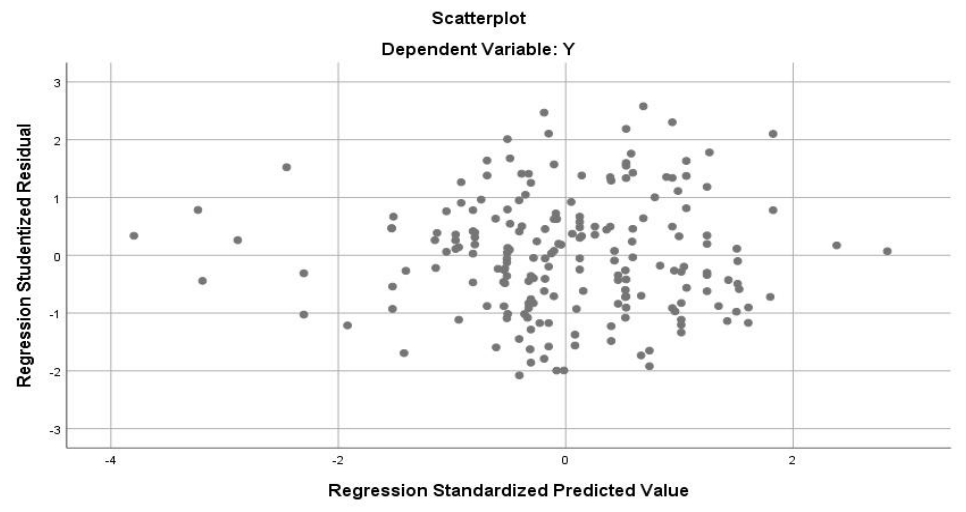

Gambar 1. Uji Hasil Heteroskedatisitas

Dari Gambar 1. dapat dilihat bahwa titik data tidak membentuk pola tertentu (membentuk pola acak). Sehingga dapat disimpulkan bahwa tidak terjadi heteroskedastisitas pada model analisis persamaan ini.

\section{Hasil Penelitian}

\section{Analisis Regresi Linear Berganda}

Analisis regresi linear berganda adalah analisis yang bertujuan untuk mengetahui hubungan fungsional antara variabel bebas (independent) secara bersama-sama terhadap variabel terikat (dependent).

Tabel 6

Hasil Analisis Regresi Linier Berganda

\begin{tabular}{llrrrrr}
\hline & Model & \multicolumn{2}{c}{$\begin{array}{c}\text { Standardized } \\
\text { Unstandardized Coefficients } \\
\end{array}$} & B & Std. Error & \multicolumn{2}{c}{$\begin{array}{c}\text { Coefficients } \\
\text { Beta }\end{array}$} & T & \multicolumn{1}{c}{ Sig. } \\
\hline 1 & (Constant) & 0,085 & 0,027 & & 3,208 & 0,002 \\
& X1 & 0,159 & 0,068 & 0,168 & 2,341 & 0,020 \\
& X2 & $-0,043$ & 0,049 & $-0,063$ & $-0,881$ & 0,379
\end{tabular}




\begin{tabular}{llllll} 
X3 & $-0,010$ & 0,015 & $-0,046$ & $-0,639$ & 0,524 \\
$\mathrm{X} 4$ & $-0,133$ & 0,060 & $-0,158$ & $-2,224$ & 0,027 \\
\hline
\end{tabular}

Berdasarkan Tabel 6 diatas maka Persamaan regresi linear berganda dalam penelitian sebagai berikut:

$$
Y=0,085+0,159 X_{1}-0,043 X_{2}-0,010 X_{3}-0,133+0,027
$$

Adapun interpretasi dari persamaan diatas adalah sebagai berikut:

a) Konstanta $(\alpha)$

Nilai konstanta sebesar 0,085 artinya adalah apabila variabel-variabel independen bernilai nol, maka besarnya manajemen laba yang terjadi adalah 0,085

b) Koefisien regresi ( $\beta$ ) CSR

Nilai koefisien CSR sebesar 0,159 hal ini menunjukkan jika variabel CSR meningkat satu satuan maka variabel nilai perusahaan akan naik sebesar 0,159 dengan asumsi variabel lainnya tetap.

c) Koefisien regresi $(\beta) \mathrm{KI}$

Nilai koefisien KI sebesar -0,043 hal ini menunjukkan jika variabel KI meningkat satu satuan maka variabel manajemen laba akan menurun sebesar -0,043 dengan asumsi variabel lainnya tetap.

d) Koefisien regresi $(\beta) \mathrm{KA}$

Nilai koefisien KA sebesar -0,010 hal ini menunjukkan jika variabel KA meningkat satu satuan maka variabel nilai perusahaan akan menurun sebesar -0,010 dengan asumsi variabel lainnya tetap.

e) Koefisien regresi $(\beta) \mathrm{KM}$

Nilai koefisien KM sebesar -0,133 hal ini menunjukkan jika variabel KM meningkat satu satuan maka variabel nilai perusahaan akan menurun sebesar -0,133 dengan asumsi variabel lainnya tetap.

\section{Uji F (Silmutan)}

$F_{\text {hitung yang lebih besar daripada }} \mathrm{F}_{\text {tabel }}$ menunjukan model regresi linear berganda yang digunakan dapat dilanjutkan atau diterima.

\section{Tabel 7}

Hasil Uji Statistik F

\begin{tabular}{rlrrrrr}
\hline & Model & Sum of Squares & df & Mean Square & F & Sig. \\
\hline 1 & Regression & 0,054 & 4 & 0,013 & 2,880 &, $024^{\text {b }}$ \\
& Residual & 0,887 & 190 & 0,005 & & \\
& Total & 0,941 & 194 & & & \\
\hline
\end{tabular}

Uji statistik F digunakan untuk mengetahui apakah semua variabel independen mempunyai pengaruh secara bersama-sama terhadap variabel dependen (Imam Ghozali, 2018).

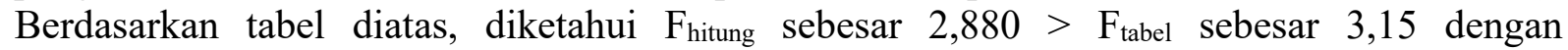
signifikansi $0,00^{\mathrm{b}}<0,05$. Hasil ini menunjukkan hipotesis alternatif $\mathrm{Ha}$ diterima dan $\mathrm{H}_{0}$ ditolak. Maka dapat disimpulkan bahwa secara bersama-sama variabel Kualitas Akrual $\left(\mathrm{X}_{1}\right)$ dan Risiko Pasar $\left(\mathrm{X}_{2}\right)$ berpengaruh dan signifikan terhadap variabel Sinkronitas Harga Saham (Y). 


\section{Uji t (Parsial)}

Pengambilan keputusan pada pengujian ini adalah jika nilai signifikan lebih besar dari $\alpha$ maka hipotesis (Ha) ditolak (koefisien regresi tidak signifikan), yang berarti secara individual variabel independen tidak mempunyai pengaruh yang signifikan terhadap variabel dependen. Jika nilai signifikan lebih kecil dari $\alpha$ maka hipotesis (Ha) diterima (koefisien regresi signifikan), berarti secara individual variabel independen mempunyai pengaruh yang signifikan terhadap variabel dependen.

Uji statistik $\mathrm{t}$ pada dasarnya ditunjukkan seberapa jauh pengaruh satu variabel independen secara individual dalam menerangkan variabel-variabel dependen (Imam Ghozali, 2018). Kriteria penerimaan dan penolakan hipotesis adalah jika $\mathrm{T}_{\text {hitung }}>\mathrm{T}_{\text {tabel, }}$ maka Ha diterima (ada pengaruh signifikan). Jika $\mathrm{T}_{\text {hitung }}<\mathrm{T}_{\text {tabel, }}$, maka Ha ditolak (tidak ada pengaruh). Nilai signifikan kecil dari $0.05(\alpha=5 \%)$, maka variabel independen tersebut secara parsial berpengaruh signifikan terhadap variabel dependen, sehingga hipotesis diterima. Apabila nilai signifikan besar dari 0,05 maka variabel independen tersebut secara parsial tidak berpengaruh terhadap variabel dependen. Berdasarkan hasil olahan data statistik pada Tabel 6, maka dapat diketahui pengaruh antara variabel independen terhadap variabel dependen secara parsial sebagai berikut:

a) Hipotesis pertama dalam penelitian ini adalah CSR berpengaruh negatif terhadap manajemen laba. Berdasarkan tabel diketahui $\beta$ (koefisien regresi) 0,159 dan nilai signifikan $0,020<0,05$ yang menunjukkan bahwa CSR berpengaruh positif signifikan terhadap manajemen laba, sehingga dapat disimpulkan bahwa hipotesis 1 ditolak.

b) Hipotesis kedua dalam penelitian ini adalah komisaris independen berpengaruh negatif terhadap manajemen laba. Berdasarkan tabel diketahui $\beta$ (koefisien regresi) $-0,043$ nilai signifikan 0,379 >0,05 yang menunjukkan komisaris independen tidak berpengaruh negatif signifikan terhadap manajemen laba, sehingga dapat disimpulkan bahwa hipotesis 2 ditolak.

c) Hipotesis kedua dalam penelitian ini adalah komisaris independen berpengaruh negatif terhadap manajemen laba. Berdasarkan tabel diketahui $\beta$ (koefisien regresi) $-0,010$ nilai signifikan $0,524>0,05$ yang menunjukkan komite audit tidak berpengaruh negatif signifikan terhadap manajemen laba, sehingga dapat disimpulkan bahwa hipotesis 2 ditolak.

d) Hipotesis pertama dalam penelitian ini adalah kepemilikaan manajerial berpengaruh negatif terhadap manajemen laba. Berdasarkan tabel diketahui $\beta$ (koefisien regresi) 0,133 dan nilai signifikan $0,027<0,05$ yang menunjukkan bahwa kepemilikan manajerial berpengaruh negatif signifikan terhadap manajemen laba, sehingga dapat disimpulkan bahwa hipotesis 1 diterima.

\section{Uji Determinasi Adjusted R-Square}

Pengambilan keputusan dal pengujian ini adalah Apabila angka koefisien determinasi semakin mendekati 1 (semakin besar), maka pengaruh variabel bebas (independent) terhadap variabel terikat (dependent) adalah semakin kuat, yang berarti variabel-variabel bebas (independent) memberikan hampir seluruh informasi yang dibutuhkan untuk memperkirakan variasi variabel terikat (dependent). Jika koefisien determinasi (adjusted $R^{2}$ ) yang kecil (menjauhi 1) yang berarti bahwa kemampuan variabel-variabel bebas (independent) dalam menerangkan variasi variabel terikat (dependent) adalah semakin lemah atau terbatas. 
Tabel 8

Hasil Uji Determinasi Adjusted R-Square

\begin{tabular}{|c|c|c|c|c|}
\hline Model & $\mathrm{R}$ & R Square & $\begin{array}{l}\text { Adjusted R } \\
\text { Square }\end{array}$ & $\begin{array}{l}\text { Std. Error of } \\
\text { the Estimate }\end{array}$ \\
\hline 1 & ,239 & 0,057 & 0,037 & 0,06834 \\
\hline
\end{tabular}

Uji determinasi Adjusted $R$ Square digunakan apabila terdapat beberapa variabel independen dalam penelitian yang berguna untuk melihat seberapa jauh kemampuan model dalam menerangkan variansi variabel dependen. Nilai koefesien determinasi yaitu antara nol dan satu, apabila nilai $\mathrm{R}^{2}$ mendekati 0 maka kemampuan variabel-variabel independen dalam menjelaskan variabel dependen terbatas. Berdasarkan hasil output diatas menunjukkan besarnya nilai Adjusted $\mathrm{R}^{2}$ adalah 0,037 atau 3,7\%. Hal ini berarti bahwa besar pengaruh dapat dijelaskan oleh variasi dari variabel independen (CSR, Komisaris Independen, Komite Audit dan Kepemilikan Manajerial) terhadap variabel dependen (Manajemen Laba) adalah $96,3 \%$.

\section{PEMBAHASAN}

\section{Pengaruh Corporate Social Responsibility (CSR) terhadap Manajemen Laba.}

Hasil penelitian pertama menunjukkan bahwa CSR berpengaruh positif terhadap manajemen laba, artinya perusahaan yang memiliki nilai CSR yang tinggi maka dapat meningkatkan aktifitas manajemen laba. Menurut (Kim et al., 2012), Corporate Social Responsibility (CSR) atau tanggung jawab sosial dan lingkungan adalah kegiatan tanggung jawab sosial yang diungkapkan oleh perusahaan agar investor, pelanggan, dan pihak stakeholder lainnya dapat menuntut transparansi yang lebih besar mengenai semua aspek bisnis. Adanya aktivitas pengungkapan CSR membuat manajemen dalam perusahaan lebih bebas untuk melakukan tindakan manajemen laba, karena aktivitas CSR ini dapat membuat respon positif dimata investor maupun masyarakat sehingga dapat menutupi kecurangan kecurangan yang dilakukan oleh manajer.

Hal ini didukung oleh penelitian (Suryani \& Herianti, 2015) dan (Wardani, 2018) yang menunjukkan bahwa CSR digunakan oleh manajemen sebagai tameng untuk menutupi praktik manajemen laba. Hal ini berarti dengan tingkat pengungkapan sosial dan lingkungan yang tinggi maka akan meningkatkan aktifitas manajemen laba.

\section{Pengaruh Komisaris Independen terhadap Manajemen Laba.}

Hasil penelitian kedua menunjukkan bahwa komisaris independen tidak berpengaruh terhadap manajemen laba, artinya perusahaan dengan komisaris independen yang tinggi tidak dapat membatasi praktik manajemen laba dikarenakan beberapa kondisi diantaranya koordinasi yang mungkin belum maksimal dan adanya pemilik yang lebih berkuasa menyebabkan tugasnya masih belum independen, serta pemenuhan mekanisme ini dimungkinkan hanya sebuah formalitas atau untuk dapat memenuhi regulasi saja. Penempatan atau penambahan anggota dewan komisaris independen dimungkinkan hanya sekedar memenuhi ketentuan formal, sementara pemegang saham mayoritas (pengendali/founders) masih memegang peranan penting sehingga kinerja dewan tidak meningkat bahkan turun (Boediono, 2005). Sejalan dengan hasil penelitian (Sutino \& Khoiruddin, 2016) dan (Arlita, R, Bone \& Kesuma, 2019) menemukan bukti bahwa komisaris independen belum dapat membatasi praktik manajemen laba karena pemenuhan mekanisme ini hanya sebuah formalitas untuk dapat memenuhi regulasi saja. 


\section{Pengaruh Komite Audit terhadap Manajemen Laba.}

Berdasarkan penelitian yang telah dilakukan dapat dikatakan tidak terdapat cukup bukti bahwa komite audit berpengaruh negatif terhadap manajemen laba. Hal ini dapat dilihat dari koefisien regresi sebesar -0,005 dimana nilai ini menunjukkan arah negatif dan nilai signifikansi sebesar 0,767> 0,05 maka dapat disimpulkan bahwa komite audit tidak berpengaruh signifikan terhadap manajemen laba pada perusahaan manufaktur. Sehingga hasil penelitian ini tidak sejalan dengan hipotesis yang diajukan penulis. Hal ini menunjukkan bahwa komite audit yang dibentuk hanya bersifat mandatory terhadap peraturan yang berlaku. Selain itu, definisi financial literacy yang harus dimiliki oleh anggota komite audit kurang jelas yang menyebabkan tiap perusahaan sampel kemungkinan memiliki definisi yang berbeda dalam menentukan kriteria dari komite audit ini. Selain itu, peraturan BAPEPAM belum menjelaskan karakteristik apa sajakah yang harus dimiliki oleh seseorang agar dapat dinyatakan memiliki financial literacy. Hal ini berpengaruh pada penunjukan anggota komite audit yang memiliki financial literacy.

Hasil penelitian ini sejalan dengan penelitian yang dilakukan oleh (Suri \& Dewi, 2018) dan (Sutino \& Khoiruddin, 2016) bahwa komite audit tidak berpengaruh terhadap manajemen laba. Hal ini kemungkinan disebabkan oleh pembentukan komite audit yang didasari sebatas untuk pemenuhan regulasi mensyaratkan perusahaan harus mempunyai koite audit. Sehingga mengakibatkan kurang efektifnya peran komite audit dalam memonitor kinerja manajemen.

\section{Pengaruh Kepemilikan Manajerial terhadap Manajemen Laba}

Berdasarkan penelitian yang telah dilakukan dapat dikatakan bahwa terdapat cukup bukti bahwa kepemilikan manajerial berpengaruh negatif terhadap manajemen laba. Hal ini dapat dilihat dari koefisien regresi sebesar -0,133 dimana nilai ini menunjukkan arah negatif dan nilai signifikansi sebesar 0,027 $<0,05$ maka dapat disimpulkan bahwa kepemilikan manajerial berpengaruh signifikan terhadap manajemen laba pada perusahaan manufaktur. Sehingga hasil penelitian ini sejalan dengan hipotesis yang diajukan penulis. Kepemilikan saham perusahaan juga dapat meminimalisir praktik manajemen laba (Abdillah, 2014). Hal ini dikarenakan kepemilikan manajerial akan meningkatkan prinsip dari GCG yaitu prinsip transparansi yang diwujudkan dalam bentuk keterbukaan dalam melaksanakan proses pengambilan keputusan dan dalam mengumumkan informasi material yang relevan mengenai perusahaan. Kepemilikan manajerial yang besar dapat mensejajarkan antara kepentingan pemilik atau pemegang saham dengan kepentingan manajer (Jensen \& Meckling, 1976), sehingga secara langsung manajer ikut merasakan manfaat dari keputusan yang diambil dan ikut pula menanggung kerugian sebagai konsekuensi dari pengambilan keputusan yang salah.

Hasil penelitan (Wijayanti, P. R., \& Subardjo, 2018) dalam penelitiannya pada pasar modal Indonesia telah membuktikan bahwa kepemilikan manajerial mampu menjadi mekanisme good corporate governance yang dapat mengurangi masalah ketidakselarasan kepentingan anatara manajer dengan dengan pemilik perusahaan. Semakin besar kepemilikan manajer pada perusahaan, maka semakin rendah kecenderungan manajer melakukan aktivitas manajemen laba. Hal itu dikarenakan adanya keselarasan tujuan manajer dengan tujuan pemegang saham.

\section{SIMPULAN, KETERBATASAN DAN SARAN Kesimpulan}

Merujuk pada hasil analisis, pengujian hipotesis, dan pembahasan serta temuan penelitian, maka dapat dikemukakan beberapa simpulan penelitian sebagai berikut:

1. Pengungkapan CSR berpengaruh signifikan positif terhadap manajemen laba pada perusahaan manuaktur yang terdaftar di BEI tahun 2015-2019. 
2. Dewan komisaris independen tidak berpengaruh signifikan negatif terhadap manajemen laba pada perusahaan manufaktur yang terdaftar di BEI tahun 2015-2019.

3. Komite audit tidak berpengaruh signifikan negatif terhadap manajemen laba pada perusahaan manufaktur yang terdaftar di BEI tahun 2015-2019.

4. Kepemilikan manajerial berpengaruh signifikan negatif terhadap manajemen laba pada perusahaan manufaktur yang terdaftar di BEI tahun 2015-2019.

\section{Keterbatasan}

Meskipun peneliti telah berusaha merancang dan mengembangkan penelitian sedemikian rupa, namun masih terdapat beberapa keterbatasan dalam penelitian yaitu:

1. Penelitian ini baru memberikan gambaran mengenai manajemen laba pada sektor manufaktur, sehingga data penelitian ini tidak mewakili seluruh perusahaan.

2. Sampel yang diambil untuk penelitian ini hanya dilakukan pada perusahaan manufaktur, sehingga hasil yang didapatkan dalam penelitian ini tidak dapat digeneralisasikan untuk seluruh perusahaan yang terdaftar di BEI.

\section{Saran}

Berdasarkan hasil penelitian ini, terdapat beberapa saran untuk perbaikan penelitian selanjutnya sebagai berikut:

1. Bagi peneliti selanjutnya diharapakn untuk dapat menggunakan jenis perusahaan yang berbeda-beda dan menggunakan ruang lingkup sampel yang lebih luas.

2. Bagi peneliti selanjutnya diharapkan untuk dapat memperpanjang jangka waktu penelitian sehingga penelitian yang dilakukan lebih berkualitas.

3. Bagi peneliti selanjutnya yang memiliki ketertarikan untuk melakukan penelitian dengan judul yang sama, sebaiknya mempertimbangkan dan mencari variabel independen lainnya yang berhubungan dengan manajemen laba.

\section{DAFTAR PUSTAKA}

Abdillah, S. Y. et al. (2014). Pengaruh Good Corporate Governance Pada Manajemen Laba ( Studi Empiris pada Perusahaan Manufaktur yang Terdaftar di Bursa Efek Indonesia Tahun 2013-2014 ). Journal Riset Mahasiswa Akuntansi (JRMA), 1-14.

Abduh, M. M., \& Rusliati, E. (2018). Mekanisme Good Corporate Governance, Leverage Dan Kinerja Keuangan Perusahaan. Jurnal Riset Bisnis Dan Manajemen, 11(2), 80-87. https://doi.org/10.34010/jra.v9i1.534

Anggana, G. R., \& Prastiwi, A. (2013). Analisis Pengaruh Corporate Governance Terhadap Praktik Manajemen Laba (Studi pada Perusahaan Manufaktur di Indonesia). Diponegoro Journal of Accounting, 2(3), 323-334.

Anwar, Y., \& Mulyadi, M. S. (2015). Impact for Corporate Social Responsibility Toward Firm Value and Profitability. The Business Review.

Ardiani, N. N., \& Sudana, I. P. (2018). Pengaruh Corporate Social Responsibility Pada Manajemen Laba. Jurnal Akuntansi Universitas Udayana, 24(3).

Arief, A. (2014). Pengaruh Pengungkapan Corporate Social Responsibility terhadap Manajemen Laba (Studi Kasus Pada Perusahaan Non Keuangan dan Jasa yang Terdaftar di BEI tahun 2010-2012). Diponegoro Journal of Accounting, 3(3), 1-9.

Arlita, R, Bone, H., \& Kesuma, A. I. (2019). Pengaruh Good Corporate Governance dan Leverage Terhadap Praktik Manajemen Laba. JEBVI, 16(2).

Boediono, G. S. B. (2005). Kualitas Laba: Studi Pengaruh Mekanisme Corporate Governance dan Dampak Manajemen Laba dengan Menggunakan Analisis Jalur. Prosiding Simposium Nasional Akuntansi VIII. 
Dai, Y., Kong, D., \& Wang, L. (2013). Information Asymmetry, Mutual Funds and Earnings Management: Evidence from China. China Journal of Accounting Research.

Ellen dan Juniarti. (2013). Penerapan Good Corporate Governance, Dampaknya Terhadap Prediksi Financial Distress pada Sektor Aneka Industri dan Barang Konsumsi periode 2008-2010. Journal Business Accounting Review, 1(2).

FASB. (1980). Statement of Financial Accounting Concepts No. 1. Objectives of Financial Reporting by Business Enterprises.

Firdausya, Z. S., Swandari, F., \& Effendi, W. (2013). Pengaruh Mekanisme Good Corporate Governance (Gcg) Pada Nilai Perusahaan (Studi Pada Perusahaan Yang Masuk Indeks LQ45 Di Bursa Efek Indonesia). Jurnal Wawasan Manajemen, 1(3), 407-424.

Forum for Corporate Governance in Indonesia (FCGI). (2001). Seri Tata Kelola (Corporate Governance) (Jilid II). www.fcgi.org.id.

Ghozali, I., \& Chairi, A. (2014). Teori Akuntansi. Universitas Diponegoro.

Ghozali, Imam. (2018). Aplikasi Analisis Multivariet dengan Program SPSS. Universitas Diponegoro.

Jensen, \& Meckling. (1976). The Theory of The Firm: Manajerial Behaviour, Agency Cost, and Ownership Structure. Journal of Financial and Economics, 3, 305-360.

Kim, Y., Park, M. S., \& Wier, B. (2012). Is earnings quality associated with corporate social responsibility? The Accounting Review, 87(3), 761-796.

Mangkusuroyo, Y., \& Jati, A. W. (2017). Pengaruh Mekanisme Good Corporate Governance Terhadap Manajemen Laba. Jurnal Reviu Akuntansi Dan Keuangan, 7(2), 1067-1080.

Prabaningrat, I. G. A. A. (2015). Pengaruh Good Corporate Governance Dan Fakultas Ekonomi dan Bisnis Universitas Udayana (Unud), Bali , Indonesia. 3(8), 663-676.

Pratiwi, Y. D., \& Wahyu, M. (2013). Pengaruh Penerapan Corporate Governance Terhadap Earnings Management Melalui Manipulasi Aktivitas Riil. Diponegoro Journal of Accounting.

Putri, G. V., \& Rohman, A. (2016). Pengaruh Pengungkapan Corporate Social Responsibility Dan Profitabilitas Terhadap Manajemen Laba. Diponegoro Journal of Accounting, 5(2), $1-11$.

Rahmawati, A., \& Triatmoko, H. (2007). Analisis Faktor-Faktor yang Mempengaruhi Kualitas Laba dan Nilai Perusahaan. Simposium NasionalX.

Scott, W. R. (2006). Financial Accounting Theory (Fourth Edi). Toronto.

Subramanyam, K. . D. J. J. W. (2010). Analisis Laporan Keuangan (Edisi 10 B). Salemba Epat.

Sulistyanto, H. S. (2008). Manajemen Laba. Teori Dan model Empiris. Grasindo.

Suri, N., \& Dewi, I. P. (2018). Pengaruh Mekanisme Good Corporate Governance terhadap Manajemen Laba. Jurnal Sains Manajemen Dan Akuntansi, $x(2)$.

Suryani, A., \& Herianti, E. V. A. (2015). Pengaruh Pengungkapan Tanggung Jawab Sosial Perusahaan terhadap Koefisen Respon Laba dan Manajemen Laba. Simposium Nasional Akuntansi XVIII. Medan.

Sutino, E. R. D., \& Khoiruddin, M. (2016). Pengaruh Good Corporate Governance terhadap Manajemen Laba pada Perusahaan yang Masuk dalam JII (Jakarta Islamic Index) Tahun 2012-2013. Management Analysis Journal, 5(3), 156-166.

Ujiyantho, A. M., \& Pramuka, B. A. (2007). Mekanisme Corporate Governance, Manajemen Laba dan Kinerja Keuangan. Prosiding Simposium Nasional Akuntansi X. Makassar.

Wardani, D. K. (2018). Pengaruh Tax Planning, Ukuran Perusahaan, Corporate Social Responsibility ( Csr ) Terhadap Manajemen Laba. 6(1), 11-24.

Wardhani, D. R., \& Joseph, H. S. (2010). Karakteristik Pribadi Komite Audit Dan Praktik Manajemen Laba. Simposium Nasional Akuntansi XIII Purwakoto. 
Wijayanti, P. R., \& Subardjo, A. (2018). Pengaruh Mekanisme Good Corporate Governance, Kebijakan Dividen, Dan Profitabilitas Terhadap Manajemen Laba. Jurnal Ilmu Dan Riset Akuntansi.

Yayasan Pendidikan Pasar Modal Indonesia (YPPMI). (2002). The Essence of Good Corporate Governance. Konsep dan Implementasi Perusahaan Publik dan Korporasi Indonesia. 